\title{
Author Index
}

Bain, B.J. 1, 120

Barnes, D.J. 9

Chase, A. 32

Cross, N.C.P. 62,69

Fioretos, T. 44

Goldman, J.M. 32

Gupta, R. 120

Hall, G.W. 80

Johansson, B. 44

Kaeda, J. 32

Knight, C.L. 120

Macdonald, D. 62

Melo, J.V. 9

Mitelman, F. 44

Pahl, H.L. 90

Reilly, J.T. 102

Reiter, A. 62

Steer, E.J. 69

Steensma, D.P. 109

Tefferi, A. 109 